\title{
Pengembangan Modul Pembelajaran IPA Digital Berbasis Flipbook Untuk Pembelajaran Daring di Sekolah Dasar
}

\author{
Agnes Herlina Dwi Hadiyanti \\ Universitas Sanata Dharma, Yogyakarta, Indonesia \\ *Corresponding author: agnes.hadiyanti@gmail.com
}

\begin{abstract}
This research is motivated by the need for teaching materials in the form of digital science learning modules for students that can be easily accessed online for online learning during the COVID-19 pandemic. The objective of this study is to develop a flipbook-based Digital Science learning module for fourth grade elementary school students. This research was conducted by applied Research and Development (RED). This reseacrh implemented ADDIE procedure which consist of five stages, namely analysis, design, development, implementation, and evaluation. The data of this research were obtained through questionnaires and interviews. The data collected were analyzed using quantitative and qualitative technique. The results showed that the quality of the learning module based on validation by four validator experts is "very good" (mean score 3.56) in accordance with material content and presentation aspect. The result of this study revealed that the module is appropriate to be used by fourth grade elementary school students
\end{abstract}

Keyword: digital module; flipbook; science

\begin{abstract}
ABSTRAK
Penelitian ini dilatarbelakangi oleh adanya kebutuhan terhadap bahan ajar berupa modul pembelajaran IPA digital untuk siswa yang bisa diakses dengan mudah secara online untuk pembelajaran daring pada masa pandemi ini. Penelitian ini bertujuan untuk mengembangkan modul pembelajaran IPA Digital berbasis flipbook untuk siswa kelas IV Sekolah Dasar. Penelitian ini merupakan jenis penelitian dan pengembangan (Research and Development) dengan menggunakan prosedur pengembangan ADDIE yang terdiri dari 5 tahap yaitu analisis (Analysis), perancangan (Design), pengembangan (Development), Implementasi (Implementation), dan evaluasi (Evaluation). Teknik pengumpulan data pada penelitian ini menggunakan wawancara dan kuesioner. Teknik analisis data yang digunakan adalah teknik analisis data kualitatif dan analisis data kuantitatif. Hasil penelitian menunjukkan bahwa kualitas modul pembelajaran berdasarkan validasi oleh 4 validator termasuk dalam kategori "sangat baik" dengan skor 3,56. Hal ini menunjukkan bahwa produk modul pembelajaran IPA digital berbasis flipbook yang dikembangkan layak digunakan untuk pembelajaran IPA di kelas IV SD.
\end{abstract}

Kata Kunci: modul digital; flipbook; IPA

\section{Pendahuluan}

Pandemi covid-19 yang terjadi saat ini memberikan dampak perubahan yang cukup signifikan pada berbagai aspek kehidupan, termasuk pada bidang pendidikan. Perubahan itu telah mengubah cara pandang dan praktik-praktik pembelajaran dunia pendidikan saat ini. Perkembangan pendidikan era digital memungkinkan siswa mampu mendapatkan pengetahuan berlimpah serta cepat dan mudah. Era digital merupakan era dimana semua aspek dalam kehidupan, termasuk dalam proses pembelajaran yang terjadi lebih banyak memanfaatkan media digital. Perubahan pendidikan di era digital mengharuskan guru memiliki kemampuan mengintegrasikan teknologi informasi dan komunikasi ke dalam proses pembelajaran (Ramadhani \& Zulela, 2020). Perubahan pada bidang pendidikan akibat pandemi covid-19 menyebabkan proses pembelajaran yang semula dilakukan melalui tatap muka harus dilakukan dengan sistem pembelajaran jarak jauh atau sistem pembelajaran dalam 
jaringan (daring). Kegiatan belajar dengan sistem pembelajaran daring seperti ini menuntut siswa untuk memiliki kemandirian dalam belajar.

Perubahan ini juga terjadi pada pembelajaran IPA di sekolah dasar. Hal ini tentunya perlu mendapat perhatian yang lebih oleh guru SD. Ilmu pengetahuan alam (IPA) adalah pengetahuan yang rasional dan objektif tentang alam semesta dengan segala isinya (Darmojo dalam Samatowa, 2011). Pembelajaran IPA menjadi salah satu wahana bagi peserta didik untuk mempelajari diri sendiri dan alam sekitar, serta dapat dikembangkan lebih lanjut untuk diterapkan dalam kehidupan sehari-hari (Andriana et al., 2020). Selain itu, pembelajaran IPA juga akan menghasilkan sumber daya manusia yang kritis, peka terhadap lingkungan, serta mampu menyelesaikan permasalahan dalam kehidupan sehari-hari (Iskandar dan Kusmayanti, 2018). Penguasaan konsep IPA oleh siswa perlu diperhatikan guru dalam proses pembelajaran. Penguasaan konsep IPA yang baik dapat membuat siswa lebih mudah dalam menyelesaikan permasalahan terkait dan memanfaatkannya dalam kehidupan sehari-hari. Hal ini sejalan dengan pendapat Anderson dan Krathwohl (dalam Rahmah dkk., 2017) bahwa penguasaan konsep dapat membantu siswa dalam menyelesaikan suatu permasalahan yang ada dalam kejadian sehari-hari. Selain itu, siswa yang memiliki penguasaan konsep yang baik akan dapat berpikir pada tingkatan yang lebih tinggi serta akan mempermudah siswa dalam mencapai kriteria ketuntasan minimal (Azhari dkk., 2017). Oleh sebab itu, untuk dapat mencapai tujuan tersebut guru perlu memfasilitasi siswa agar dapat belajar dengan optimal dalam proses pembelajaran. Berdasarkan hal tersebut, guru perlu memfasilitasi siswa dalam pembelajaran IPA agar kegiatan pembelajaran dapat berjalan dengan optimal.

Pendidik berperan mengatur lingkungan agar tercipta interaksi belajar mengajar antara siswa, guru, dan sumber belajar lainnya untuk mencapai tujuan pembelajaran. Sumber belajar berupa semua sumber, baik berupa data, orang maupun benda yang dapat digunakan untuk memberi fasilitas atau kemudahan belajar bagi siswa (Asosiasi Tekonologi Komunikasi dalam Prastowo, 2018). Sumber belajar berkaitan dengan komponen-komponen dalam proses belajar mengajar, salah satunya adalah penggunaan bahan ajar. Bahan ajar menjadi salah satu komponen yang utama karena kegiatan pembelajaran tidak bisa diselenggarakan tanpa adanya bahan ajar (Prastowo, 2018). Bahan ajar diperlukan guru sebagai acuan penyampaian materi kepada siswa. Sedangkan bagi siswa, bahan ajar menjadi sumber belajar yang menampilkan kompetensi yang akan dikuasai.

Beberapa penelitian menunjukkan bahwa dalam pembelajaran IPA seringkali belum berjalan dengan baik. Salah satu faktor penyebabnya adalah ketersediaan bahan ajar yang belum memadai. Hermawan (2017) mengungkapkan bahwa ketersediaan bahan ajar yang variatif dan menarik seringkali tidak ditemukan di sekolah dasar. Lebih lanjut, Berdasarkan hasil analisis kebutuhan melalui wawancara dengan tiga orang guru kelas IV SD, diketahui bahwa guru membutuhkan suatu bahan ajar berupa modul pembelajaran yang berisi materi yang lengkap dan komprehensif yang dapat digunakan siswa dalam proses pembelajaran daring pada masa pandemi seperti sekarang ini. Selain itu, berdasarkan hasil kuesioner yang diisi oleh siswa diperoleh data bahwa produk pembelajaran yang dibutuhkan oleh siswa saat ini adalah berupa modul pembelajaran yang mudah diakses dan menarik, serta memuat penjelasan materi pembelajaran yang lengkap dan terperinci serta juga dilengkapi dengan panduan aktivitas-aktivitas belajar mandiri dan juga soal-soal latihan untuk mengecek pemahaman siswa terhadap konsep materi yang dipelajari. 
Bahan ajar tidak hanya berupa buku atau LKS yang berbasis media cetak. Bahan ajar berbasis non cetak juga dapat digunakan dalam pembelajaran misalnya dalam bentuk bahan ajar elektronik. Saat ini bahan ajar berbasis elektronik dapat dengan mudah diperoleh karena hadirnya perangkat jaringan teknologi informasi. Melalui jaringan teknologi informasi tersebut guru dapat memanfaatkannya menjadi bahan ajar dengan mudah (Kuncahyono, 2018). Salah satu jenis bahan ajar yang dapat digunakan oleh siswa bisa berupa modul pembelajaran. Modul disusun guna kepentingan siswa yang berisi rangkaian kegiatan belajar yang disesuaikan dengan kompetensi yang harus dicapai. Modul merupakan seperangkat bahan ajar yang disajikan secara sistematis sehingga siswa dapat belajar tanpa seorang guru, disusun secara sistematis dan menarik yang mencakup isi materi, metode, dan evaluasi yang dapat digunakan secara mandiri (Sukardi, 2018; Depdiknas, 2008). Sejalan dengan pendapat tersebut, Prastowo (dalam Nurbaeti \& Sunarsih, 2020) mengemukakan bahwa modul adalah sebuah bahan ajar yang disusun secara sistematis dengan bahasa yang mudah dipahami oleh siswa sesuai tingkat pengetahuan dan usia mereka, agar mereka dapat belajar sendiri (mandiri) dengan bantuan atau bimbingan yang minimal dari guru. Hal ini sesuai dengan paradigma pendidikan saat ini dimana pembelajaran lebih berpusat pada siswa (student centered learning) dan guru berperan sebagai fasilitator pembelajaran. Seiring berkembangnya ilmu pengetahuan dan teknologi, modul mulai bertransformasi menjadi modul digital, yaitu modul yang bisa diakses melalui laptop, komputer dan lainya. Modul digital ini berwujud teks, gambar, video dan audio. Modul digital ini sangat cocok dimanfaatkan untuk sistem belajar jarak jauh (pembelajaran daring) seperti pada masa pandemi sekarang ini dan dapat membantu untuk belajar mandiri.

Modul digital yang dimaksudkan adalah modul yang dibuat secara digital berbentuk flipbook sebagai media pembelajaran yang berisi animasi, audio, dan navigasi yang menjadi lebih interaktif. Penggunaan flipbook digital ini serupa dengan buku elektronik (e-book) namun kelebihannya flipbook ini dapat dibuka lembar demi lembar yang didukung dengan animasi, video, tulisan, maupun gambar yang relevan dengan konteks buku (Khasanah \& Nurmawati, 2021). Keunggulan dari aplikasi ini yaitu (1) mampu memberikan modul efek flip atau halaman dapat dibolak-balik; (2) pembuatan modul dengan aplikasi ini sangat mudah; (3) tampilan modul tidak hanya berupa teks dan gambar saja, bentuk audio dan video dapat dikombinasikan dalam menyajikan materi; (4) produk yang dihasilkan dapat dipublikasikan dalam format SWF (Shock Wave Flash), HTML (Hyper Text Markup Language) apabila hendak dipublikasikan melalui website (Anandari, dkk., 2019).

Mengingat peran bahan ajar yang penting dan adanya kebutuhan dikembangkannya bahan ajar digital IPA untuk mengakomodasi pembelajaran daring selama pandemi, maka peneliti melakukan penelitian pengembangan yang bertujuan untuk mengembangkan modul pembelajaran IPA digital berbasis flipbook untuk pembelajaran daring bagi siswa kelas IV SD.

\section{Metode Penelitian}

Jenis penelitian yang digunakan dalam penelitian ini adalah penelitian dan pengembangan atau research and development (RED). Penelitian dan pengembangan adalah rangkaian proses atau langkah-langkah dalam rangka mengembangkan suatu produk baru atau memperbaiki produk yang telah ada agar dapat dipertanggungjawabkan (Direktorat Tenaga Kependidikan dalam Tegeh, dkk., 2014). 
Penelitian ini menggunakan model pengembangan ADDIE (Analysis, Design, Development, Implementation, Evaluation). Model ini disusun secara terprogram dengan urutanurutan kegiatan yang sistematis dalam upaya pemecahan masalah belajar yang berkaitan dengan sumber belajar yang sesuai dengan kebutuhan dan karakteristik siswa. Model ini memiliki lima langkah yang terdiri dari (1) Analyze (analisis), (2) Design (perancangan), (3) Development (pengembangan), (4) Implementation (implementasi), dan (5) Evaluation (evaluasi), yang diimplementasikan untuk mengembangkan produk pengembangan seperti buku ajar, modul pembelajaran, video pembelajaran, dan lain sebagainya (Tegeh dkk., 2014). Alur penelitian dengan menggunakan model pengembangan ADDIE disajikan dalam bagan berikut ini.

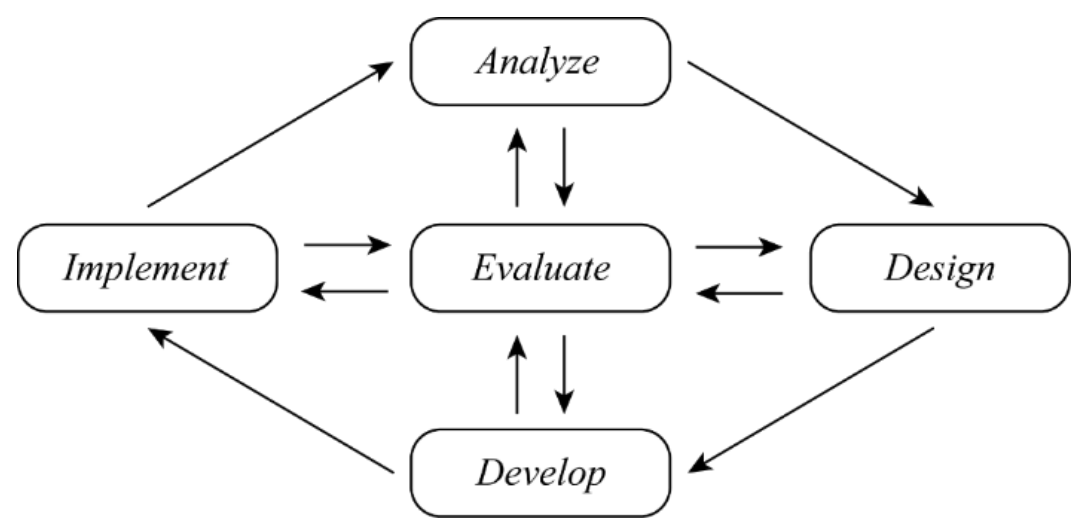

Gambar 1. Model pengembangan ADDIE

Pada tahap Analyze (analisis), peneliti melakukan needs assessment (analisis kebutuhan) melalui wawancara dan kuesioner yang bertujuan untuk mengidentifikasi produk pembelajaran yang dibutuhkan oleh siswa di sekolah. Pada tahap Design (perancangan), peneliti melakukan perancangan produk sesuai hasil analisis kebutuhan yang telah dilakukan pada tahap sebelumnya. Pada tahap Development (pengembangan) peneliti melakukan tahap produksi untuk mewujudkan rencana pengembangan yang telah dibuat dalam tahap desain menjadi bentuk yang nyata (fisik). Pada tahap Implementation (implementasi), peneliti melakukan implementasi penggunaan produk yang telah divalidasi pada tahap sebelumnya. Kemudian tahap Evaluation (evaluasi) merupakan tahap untuk mengukur atau menilai kualitas produk yang telah dikembangkan.

Teknik pengumpulan data berupa wawancara dan kuesioner. Wawancara adalah suatu cara pengumpulan data yang digunakan untuk memperoleh informasi langsung dari sumbernya (Sudaryono, 2016). Wawancara merupakan bentuk komunikasi verbal yang bertujuan untuk memperoleh informasi secara individual. Pada penelitian ini, wawancara dilakukan pada 3 orang guru kelas IV sekolah dasar dari SD Kanisius Babadan, SD Kanisius Kadirojo, SD Kanisius Sengkan, untuk mendapatkan informasi poduk pembelajaran seperti apa yang dibutuhkan. Kuesioner atau angket adalah metode pengumpulan data yang dilakukan dengan cara memberi seperangkat pertanyaan atau pernyataan tertulis kepada responden untuk diberikan respon sesuai dengan permintaan pengguna (Widoyoko, 2015). Menurut Yusuf (2015), terdapat tiga jenis kuesioner yaitu: (1) kuesioner tertutup, yang alternatif jawaban sudah ditentukan sehingga responden hanya memilih antara alternatif 
jawaban. (2) Kuesioner terbuka, yang tidak tersedia alternatif jawaban sehingga responden memiliki kesempatan untuk mengemukakan pendapat terkait pertanyaan. (3) Kuesioner tertutup dan terbuka, yang alternatif jawaban sudah tersedia dan terdapat pula kesempatan untuk responden mengemukakan alternatif jawaban sendiri. Pada penelitian ini, peneliti menggunakan jenis kuesioner tertutup dan terbuka untuk melakukan analisis kebutuhan yang ditujukan kepada siswa kelas IV sekolah dasar dan juga menggunakan kuesioner tertutup untuk melakukan validasi produk modul pembelajaran IPA digital berbasis flipbook serta untuk mengetahui tanggapan siswa terhadap produk modul pembelajaran IPA digital berbasis flipbook yang telah dikembangkan.

Teknik analisis data yang digunakan adalah teknik analisis data kualitatif dan data kuantitatif. Data kualitatif adalah data berbentuk kata-kata, bukan dalam bentuk angka (Darmadi, 2014). Data kualitatif dalam penelitian ini diperoleh dari hasil wawancara, kuesioner analisis kebutuhan, serta kuesioner tanggapan siswa. Analisis data kualitatif dilakukan dengan menyusun secara sistematis data yang diperoleh dari hasil wawancara dan teknik pengumpulan data lainnya dengan mengorganisasikan data hingga membuat kesimpulan yang dapat dipahami (Sugiyono, 2016). Data kuantitatif adalah data yang berbentuk angka, atau data kualitatif yang diangkakan (scoring) (Sugiyono, 2016). Data kuantitatif dalam penelitian ini diperoleh dari hasil skor kuesioner validasi produk, dan hasil skor kuesioner tanggapan siswa.

\section{Hasil dan Pembahasan}

Pengembangan modul pembelajaran IPA digital berbasis Flipbook untuk siswa kelas IV sekolah dasar menggunakan model ADDIE yang terdiri dari lima tahap yaitu Analyze (analisis), Design (perancangan), Development (pengembangan), Implementation (implementasi), dan Evaluation (evaluasi).

Tahap pertama dalam penelitian ini adalah tahap Analyze (analisis). Pada tahap ini peneliti melakukan analisis kebutuhan melalui wawancara dan kuesioner yang bertujuan untuk mengidentifikasi produk pembelajaran yang dibutuhkan oleh siswa di sekolah. Berdasarkan hasil wawanacara dan juga kuesioner, diketahui bahwa siswa seringkali kurang termotivasi untuk belajar saat pembelajaran daring seperti sekarang ini. Selain itu, dapat diketahui juga bahwa bahan ajar yang digunakan siswa belajar secara mandiri di rumah masih terbatas. Bahan ajar ini tentunya dapat berpengaruh terhadap pelaksanaan pembelajaran sehingga pembelajaran menjadi kurang maksimal. Siswa masih membutuhkan tambahan bahan ajar berupa modul pembelajaran yang dapat melengkapi sumber belajar untuk pembelajaran daring pada masa pandemi seperti sekarang ini. Berdasarkan hasil wawancara dan pengisian kuesioner, siswa menyukai modul pembelajaran yang menarik dan berisi penjelasan materi yang lengkap dan terperinci, serta dilengkapi dengan gambar-gambar yang dapat membantu memahami materi, kegiatan percobaan yang dapat dicoba untuk dilakukan secara mandiri di rumah, dan juga dilengkapi dengan latihan-latihan soal atau kuis serta memiliki rangkuman materi.

Tahap kedua penelitian adalah tahap Design (perancangan). Peneliti merancang modul pembelajaran IPA digital berbasis Flipbook dengan membuat kerangka modul, dan menyusun garis besar materi. Kerangka modul memuat unsur-unsur modul yaitu judul, petunjuk umum, petunjuk belajar menggunakan modul, materi modul, latihan-latihan, lembar kerja, dan 
evaluasi. Pada tahap perancangan ini, peneliti juga merancang instrumen validasi yang dibutuhkan untuk menilai kualitas produk modul pembelajaran yang dikembangkan.

Tahap ketiga penelitian ini adalah tahap Development (pengembangan). Peneliti mulai mengembangkan produk modul dengan membuat rancangan modul menjadi bentuk yang nyata. Peneliti mengumpulkan bahan materi dari berbagai referensi kemudian dikembangkan menjadi isi modul pembelajaran yang utuh. Selain itu, pada tahap ini peneliti juga melakukan validasi terhadap produk modul pembelajaran IPA digital berbasis flipbook yang telah dikembangkan. Validasi produk dilakukan oleh 4 orang validator yang terdiri dari 1 orang pakar bidang IPA dan 3 orang guru kelas IV SD. Aspek-aspek yang dinilai/divalidasi pada produk modul pembelajaran IPA digital berbasis flipbook yang dikembangkan adalah aspek konten atau isi modul pembelajaran, dan aspek desain modul pembelajaran. Berikut adalah data hasil validasi produk dari validator.

Tabel 1. Hasil Validasi Produk

\begin{tabular}{|c|c|c|c|c|}
\hline \multirow{2}{*}{ Aspek yang dinilai } & \multicolumn{4}{|c|}{ Hasil Validasi Produk } \\
\hline & Validator 1 & Validator 2 & Validator 3 & Validator 4 \\
\hline Konten atau isi modul pembelajaran & 51 & 56 & 52 & 48 \\
\hline Desain & 47 & 50 & 47 & 48 \\
\hline Total Skor Validasi & 98 & 106 & 99 & 96 \\
\hline Rerata & 3,50 & 3,79 & 3,54 & 3,42 \\
\hline Kategori & Sangat baik & Sangat baik & Sangat baik & Sangat baik \\
\hline Rerata hasil Validasi produk & \multicolumn{4}{|c|}{ 3,56 (Sangat Baik) } \\
\hline
\end{tabular}

Berdasarkan analisis data hasil validasi produk tersebut menunjukkan bahwa kualitas produk modul pembelajaran IPA digital berbasis flipbook yang telah dikembangkan masuk dalam kategori sangat baik, yang ditunjukkan dari hasil rerata skor validasi produk modul pembelajaran IPA digital berbasis flipbook adalah sebesar 3,56. Berdasarkan hasil pada tahap ini, maka produk modul pembelajaran IPA digital berbasis flipbook telah layak untuk digunakan pada tahap berikutnya yaitu tahap implementasi.

Tahap keempat penelitian adalah tahap Implementation (implementasi). Pada tahap ini peneliti melakukan implementasi penggunaan produk modul pembelajaran IPA digital berbasis flipbook yang telah divalidasi pada tahap sebelumnya. Implementasi dilakukan dengan uji coba penggunaan produk modul pembelajaran IPA digital berbasis flipbook pada pengguna yang merupakan siswa kelas IV SD.

Pada tahap kelima, peneliti melakukan evaluasi produk yang berupa penilaian (validasi) dari ahli terhadap produk yang telah dikembangkan. Berdasarkan hasil validasi yang telah dipaparkan pada tabel 1, diketahui bahwa kualitas produk modul pembelajaran IPA digital berbasis flipbook yang dikembangkan masuk dalam kategori sangat baik dan layak untuk digunakan sebagai salah satu sumber belajar dalam pembelajaran daring di sekolah dasar. Selain itu, peneliti juga melakukan evaluasi dengan meminta tanggapan atau respon dari siswa sebagai pengguna dari produk modul pembelajaran IPA digital berbasis flipbook yang telah dikembangkan ini. Berdasarkan hasil tanggapan/respon dari siswa tersebut, peneliti mengetahui bahwa produk modul pembelajaran IPA digital berbasis flipbook disenangi oleh siswa dan dapat membantu meningkatkan motivasi belajar siswa untuk mempelajari pelajaran IPA, serta dapat membantu mereka dalam mempelajari materi-materi yang dipelajari. Dengan 
penggunaan modul pembelajaran IPA digital berbasis flipbook ini siswa juga dapat termotivasi untuk belajar secara mandiri terutama pada saat pandemi seperti sekarang ini. Hal ini sesuai dengan yang dikatakan oleh Lasmiyati \& Harta (2014) bahwa modul sebagai salah satu bahan ajar mempunyai salah satu karakteristik adalah prinsip belajar mandiri. Belajar mandiri adalah cara belajar aktif dan partisipasi untuk mengembangkan diri masing-masing individu yang tidak terikat dengan kehadiran guru, dosen, pertemuan tatap muka di kelas, kehadiran teman sekolah. Pembelajaran dengan menggunakan modul pembelajaran IPA digital berbasis flipbook ini membantu siswa membangun pembelajaran yang bermakna dan menstimulasi perkembangan mereka dengan memberikan pengalaman belajar yang menyenangkan. Pengalaman belajar yang menyenangkan disediakan dalam modul melalui aktivitas-aktivitas belajar mandiri yang dibuat dalam modul dan juga termasuk menyediakan berbagai variasi latihan soal yang dapat digunakan siswa untuk melatih dan juga menguji pemahaman mereka terkait materi-materi yang dipelajari dalam modul. Hal ini diperkuat oleh penelitian (Amanullah, 2020) yang menyatakan bahwa dengan adanya modul elektronik berbasis digital flipbook dapat memaksimalkan pembelajaran di dalam kelas serta dapat membantu peserta didik dalam proses pembelajaran melalui media pembelajaran yang disajikan oleh guru. Kemudian penelitian (Yulaika, dkk., 2020) menjelaskan bahwa peserta didik mudah memahami materi yang disajikan dalam modul elektronik berbasis digital flipbook dengan adanya fitur-fitur pendukung di dalamnya sehingga hasil belajar peserta didik mengalami peningkatan. Berdasarkan hasil tanggapan/respon siswa dapat dikatakan penggunaan modul pembelajaran IPA digital berbasis flipbook ini mampu menarik minat dan motivasi siswa untuk belajar, serta dapat memudahkan siswa dalam memahami materi-materi yang dipelajari. Adanya penggunaan teknologi dalam pengembangan modul mampu meningkatkan minat dan motivasi belajar siswa. Hal ini sejalan dengan pendapat Barron (dalam Kuncahyono, 2018) bahwa penerapan teknologi interaktif dalam lingkungan pembelajaran mampu membangkitkan semangat dalam proses pembelajaran.

\section{Kesimpulan}

Berdasarkan hasil penelitian dan pembahasan yang telah dikemukakan, dapat disimpulkan bahwa kualitas produk modul pembelajaran IPA digital berbasis flipbook yang telah dikembangkan masuk dalam kategori sangat baik dengan skor rerata hasil validasi sebesar 3,56. Selain itu, berdasarkan hasil implementasi produk modul pembelajaran IPA digital berbasis flipbook dalam pembelajaran IPA, diperoleh data tanggapan/respon dari siswa kelas IV SD sebagai pengguna produk, bahwa produk modul pembelajaran IPA digital berbasis flipbook yang telah dikembangkan disenangi oleh siswa dan dapat membantu meningkatkan motivasi belajar siswa dalam pembelajaran, serta dapat membantu mereka dalam mempelajari materi-materi yang dipelajari.

\section{Daftar Pustaka}

Andriana, E., Ramadayanti, S., \& Noviyanti, T. E. (2020). Pembelajaran IPA di SD Pada Masa COVID 19. Prosiding Seminar Nasional Pendidikan FKIP, 3(1), 409-413.

Amanullah, M. A. (2020). Pengembangan Media Pembelajaran Flipbook Digital Guna Menunjang Proses Pembelajaran di Era Revolusi Industri 4.0. Jurnal Dimensi Pendidikan Dan Pembelajaran. 
Anandari, dkk. (2019). Development Of Electronic Module: Student Learning Motivation Using The Application Of Ethnoconstructivism-Based Flipbook Kvisoft. Jurnal Pedagogik. 6 (2), 416-436.

Azhari, L. M. Z., Yuliati, L., \& Suharti. (2017). Penguasaan Konsep IPA Siswa Kelas V SD Pada Materi Rangka Tubuh. Prosiding Seminar Pendidikan IPA Pascasarjana UM, 2, 30-35.

Darmadi, H. (2014). Metode Penelitian Pendidikan dan Sosial: Teori Konsep Dasar dan Implementasi. Bandung: Alfabeta.

Departemen Pendidikan Nasional. 2008. Pengembangan Bahan Ajar dan Media. Jakarta: Departemen Pendidikan Nasional.

Iskandar, R. \& Kusmayanti, I. (2018). Pendekatan Science Technology Society: IPA di Sekolah Dasar. Jurnal Ilmiah Pendidikan Guru Sekolah Dasar, 2(2), 200-215.

Khasanah, I. \& Nurmawati, I. (2021). Pengembangan Modul Digital Sebagai Bahan Ajar Biologi untuk Siswa Kelas XI IPA. Indonesian Journal of Mathematics and Natural Science Education, 2(1), 34-44.

Kuncahyono. (2018). Pengembangan E-Modul (Modul Digital) Dalam Pembelajaran Tematik Di Sekolah Dasar. JMIE: Journal of Madrasah Ibtidaiyah Education, 2(2), 219-231.

Lasmiyati \& Harta, I. (2014). Pengembangan Modul Pembelajaran untuk Meningkatkan Pemahaman Konsep dan Minat SMP. PYTHAGORAS: Jurnal Pendidikan Matematika, 9(2), 161-174.

Nurbaeti, R. U. \& Sunarsih, D. (2020). Pengembangan Modul Praktikum IPA Berbasis Kurikulum 2013 Untuk Mahasiswa Pendidikan Guru Sekolah Dasar. Jurnal Elementaria Edukasia, 3(1), 109-116.

Prastowo, A. (2018). Sumber belajar dan pusat sumber belajar: Teori dan aplikasinya di sekolah/madrasah. Jakarta: Kencana.

Rahmah, S., Yuliati, L., \& Irawan, E. B. (2017). Penguasaan Konsep IPA Pada Siswa Sekolah Dasar. Prosiding Seminar Nasional PS2DMP ULM, 3(2), 35-40.

Ramadhani, S.P., \& Zulela. (2020). Profesional Pedagogy Guru Terhadap Perubahan Pembelajaran di Era Digital. Jurnal Elementaria Edukasia, 3(1), 384-397.

Samatowa, U. (2011). Pembelajaran IPA di Sekolah Dasar. Jakarta: Indeks.

Sudaryono. (2016). Metode penelitian pendidikan. Jakarta: Prenada Media Group.

Sukardi. 2018. Metodologi Penelitian Pendidikan Kompetensi Dan Praktiknya. Jakarta: Bumi Aksara.

Sugiyono. (2016). Metode Penelitian Kuantitatif, Kualitatif dan REDD. Bandung: PT Alfabet.

Tegeh, I. M., Jampel, I. M., \& Pudjawan, K. (2014). Model Penelitian Pengembangan. Yogyakarta: Graha Ilmu.

Widoyoko, E. P. (2015). Teknik Penyusunan Instrument Penelitian. Yogyakarta: Pustaka Pelajar.

Yulaika, N. F., Harti, \& Sakti, N. C. (2020). Pengembangan bahan ajar elektronik berbasis flip book untuk meningkatkan hasil belajar peserta didik. Jurnal Pendidikan Ekonomi, Manajemen Dan Keuangan, 4(1), 67-76. https:// doi.org/10.26740/jpeka.v4n1.p67-76

Yusuf, M. (2015). Asesmen dan Evaluasi Pendidikan: Pilar Penyedia Informasi dan Kegiatan Pengendalian Mutu Pendidikan. Jakarta: Kencana. 